\title{
Effectiveness of Business Innovation and R\&D in Emerging Economies: The Evidence from Panel Data Analysis
}

\author{
M. Martin
}

\begin{abstract}
The problems of management and optimization of business innovative effort seem to be of vital importance in the contemporary economics, especially in the period of global economic slowdown. This paper is the continuation of research work aiming to assess, on the basis of estimation of transformation of Cobb-Douglas production function the effectiveness of various types of business innovation expenditures of manufacturing enterprises located in Poland. The survey is based on data obtained from public statistics (The Central Statistical Office). The econometric estimations presented in the paper are based on the total sample of maximum 191 firms permanently (every year in the time series) active in the field of $R \& D$ over the observed 10 year period between 2000 and 2009. The estimations are based on the relative EBITD growth as dependent variable. Independent variables including various categories of innovation expenditure plus non innovative capital expenditure relative to sales and relative employment growth were lagged from 0 to 6 years. The study revealed strong variation in terms of effectiveness of various categories of innovative expenditure and relatively strong and consistently positive lagged random effects (RE) of both internal and external $R \& D$ expenditure. This, together with other findings, might suggest that positive effects of business R\&D are mostly associated with specific time-invariant individual characteristics of business units.
\end{abstract}

Index Terms-Business innovation, business R\&D, effectiveness, emerging economies, fixed effects, random effects.

\section{INTRODUCTION}

The effects of innovation at the macroeconomic level are in general unquestionable in today's world. In the process of classical, from the current point of view research, it has been estimated that innovation, and especially the commercial applications of science and technological developments, account for up to $75 \%$ of economic growth. Social wealth is determined by technical progress in up to $90 \%$ [1]. These findings are consistent with more recent studies and the economic theory [2], [3] that indicate technical change as a major source of long-term productivity growth. The overall rate of return to $\mathrm{R} \& \mathrm{D}$ is quite impressive; it is estimated at $25 \%$ for private returns and at a total of $65 \%$ in terms of overall social returns [4].

Manuscript received November 10, 2013; revised January 9, 2014. This work was supported by National Science Centre in Poland under Grant number N N112 316238 with the funds allocated to science in the years 2010-2013 as the research project. Author would like to express his gratitude for funding and support of this research work.

M. Martin is with the Lodz University of Technology, Division of Economics, Wolczanska 215, 90-924 Lodz, Poland (e-mail: martin@p.lodz.pl).
On the other hand the issue of transferring business innovation expenditure into sales growth and product development is by no means straightforward at the microeconomic level. The output of business innovation and $\mathrm{R} \& \mathrm{D}$ are often unclear, indirect, and difficult to measure. This problem is even more important in the case of emerging and transition economies, since research evidence and conclusions based on research work done in developed economies might not be easily transferable due to deferent stages of development of the two types of economies. Innovation is generally considered as a tool for improving the competitiveness of firms and their performance, nevertheless this relationship has not been supported fully by empirical work.

This paper is a continuation of previous research work that was based on non-panel data analysis and econometric estimations [5], [6] regarding the issue of effectiveness of business innovation and $R \& D$ in the case of emerging and transition economies.

The general purpose of this research is twofold. In the first place it is to extent, on the basis of estimations of panel models, the previous research regarding the issue of effectiveness of business innovation activities via implementation of different methods and econometric tools applied to exploration of the issue of fixed effects and random effects of innovative and $R \& D$ business expenditure. Secondly, it is to observe the differences between results of previous classical least square (CLS) estimations based on the relative sales and EBITD growth and the present ones based on estimation of various panel models.

Previous research based on classical (non-panel) estimations revealed that relative EBITD growth as the dependent variable is to the smaller extent explained by various categories of innovation expenditure in comparison to the models based on relative sales growth. The study showed positive and constant, regardless of $R \& D$ regularity, impact of business R\&D effort over relative EBITD growth. The main aim of the current research is to examine the issue of effectiveness of business innovation and R\&D effort on the basis of panel methods of estimation of regression functions with the distinction to fixed effects (FE) and random effects (RE).

\section{LITERATURE REVIEW}

The impact of innovation on firm's performance has been a matter of significant interest to economists and policy makers for decades.

It is generally recognized that effective and successful 
innovation is difficult to accomplish and relatively rare. The study [7] related to public companies representing around $60 \%$ of global R\&D expenditures proved that above certain minimal level there is in fact no correlation between $R \& D$ spending and business performance exemplified by i.e. sales and profit. Author argues that it is in fact hard to talk about effectiveness of innovation in terms of, so to say, correlation or coexistence. It is rather hit-or-miss situation, that strongly determines the effectiveness issues and dilemmas. The key issue regarding the effectiveness is therefore not in the first place how much to spend but how to spend. The actual innovation spending of individual company should be based upon the individual "innovation effectiveness curve" that helps companies to assess the innovation spending against the financial returns from innovation expenditure.

In a recent study [8] regarding $R \& D$ expenditure and profitability in the pharmaceutical industry in the US, focusing on relationships between size adjusted R\&D budgets and standardized excess abnormal returns, it was proved that "the market does not react significantly to information on innovations or innovative activities in the pharmaceutical industry" at the same time "there is no relationships between excess abnormal returns and annual R\&D budgets".

In a study dedicated to relations between innovation investment and performance in industrial firms [9], authors stress importance of tangible investments and unit labour cost for achieving high productivity levels. R\&D expenditure and intangible capital are complementary variables of earlier mentioned aspects, that have delayed effects in terms of productivity and profitability. The actual existence of substantial economies of scale and specific capital or labor intensity in the particular sector of industry have variable, according to the size of the prior, effect on relations between innovation investment and performance of industrial firms.

Differences in the profitability of business R\&D are often attributed to the firm's technology context. Within various aspects of technology context it has been found that complexity, generality and tacitness of a firm's technology context, determined by industrial resources, influence the rate of return to investment in $R \& D$ [10].

Study related to the issue of product innovation strategies and performance of new high-tech firms in China [11] proved that the innovation effectiveness is to large extent determined by environmental factors and institutional support. Another study [12] found that there is a positive relationship between innovation activities and productivity. In making decisions regarding innovation activites firms rely on the knowledge accumulated from previously abandoned innovations and cooperation with other firms and institutions and other members of their group. Results of the study reveal several differences in behavior of firms in two groups of countries. Western Europe and advanced transition economies from Central and Eastern Europe.

According to reference [13] the acquisition of external $\mathrm{R} \& \mathrm{D}$ or cooperation with external partners in $\mathrm{R} \& \mathrm{D}$ projects exerts a positive impact upon the profitability of firms. Internal R\&D only does not significantly impact the profitability of firms. External innovation strategies are, therefore, likely to generate profit gains at the expense of a significantly high risk. R\&D (input) and innovation (output) are highly persistent at the firm level. Among external/environmental factors, market dynamism affects R\&D and innovation. Past innovative behavior is clearly more decisive in explaining the current state of $R \& D$ and innovation activities than external factors or firm-level heterogeneity [14]. On top of this firms that have R\&D that is more productive, exhibit higher and less volatile future operating performance [15]. One contribution of this study is that it demonstrates that the relation between R\&D expense (i.e., inputs) and future operating performance is better understood by incorporating information about the productivity (i.e., outputs) of a firm's R\&D outlays in the form of patent counts and citations. Internal research capabilities, particularly those with a strong basic research component, are essential to enabling a firm to generate creative outputs [16]. Research also found evidence supporting the hypothesis of increasing returns to scale to R\&D spending which is consistent with economic arguments for the advantages of scale in innovation. Profiting from innovation requires strong complementary capabilities between R\&D and other business activities within the firm, i.e. marketing and manufacturing [17]. Reference [18] emphasizes the importance of so called "behind innovation". In that respect effectiveness of commercialization strategy is vitally important. The cost of innovation must include creation of novelty, development and commercialization. The overall effect of innovation process depends on proper product positioning, well-tailored pricing policy along product life cycle. Therefore identification of effective paths for maximizing return on business innovation seems to be relatively important issue. On top of their impact on the firm's market value, innovation and R\&D may have an influence on the firm's financial performance in terms of income and sales growth. Another research indicates the relationships $R \& D$ and firm's financial performance. The firms which have higher R\&D spending obtain the higher average sales growth than the market average [19]. Reference [20] suggests important differences in terms of innovation-related factors determining the productivity growth of European companies in general (represented in the survey by Austrian, French, Dutch, and British firms) and of Italian companies in particular. This may suggest important variation regarding factors determining the effects of innovative activities even among advanced economies representing a similar level of economic development.

The problem of two way relationships and effectiveness of internal R\&D expenditures and external technology sourcing, both in the form of business R\&D contracting from external sources and $R \& D$ cooperation was examined on a basis of a sample of Flemish R\&D active companies [21]. The research was based on the basic principle that availability of external technology may limit investment in the in house research and the issue of complementarity. Author found that external technology sourcing have a significant positive effect on internal R\&D only in the situation when companies (technology recipients) "have sufficient absorptive capacity in the form of a full-time staffed R\&D department. At the same time, firms are found to be more frequently engaged in $R \& D$ cooperation, the more they spend on internal R\&D”. 
The study related to the issue of decisions between internal and external R\&D [22] proved that it is efficient for companies to engage in both types of $\mathrm{R} \& \mathrm{D}$. According to authors "internal R\&D enables the firm to translate external knowledge into innovation opportunities for the firm. External R\&D facilitates spillovers from the outside information network to the firm's specific knowledge stock". In order for the firm to engage in both types of $R \& D$ activities the need for a critical mass exists (in terms of the amount of firms R\&D effort or in terms of the quality of the firm's external environment providing sufficient technological opportunities). Authors also found that in high-tech the complementary effect between internal and external R\&D takes place whereas in low-tech industries internal and external R\&D tend to be substitutes. Among various factors determining effectiveness of business innovation including return on investment-like measures, innovation management seems to be of paramount importance. Although it has been found that the overall quality of innovation management has weakened recently, good innovation management may increase firms' profitability (expressed by EBIT) by up to $13 \%$ in comparisons with average performers [23].

\section{The Methodology AND Model}

The survey presented in this paper, regarding the panel data analysis the effectiveness of business innovative activities with special emphasis on the issue of effectiveness of business $\mathrm{R} \& \mathrm{D}$ activities in the case of emerging economies, is based on the estimation of regression function that is based on the transformation of Cobb-Douglas production function. The dependent variable in this case was defined as the relative growth of earnings before interest, tax and depreciation (EBITD), that is considered as the most suitable measure of profitability of innovative activities at the firm level, since it takes under consideration only short term costs and revenues that reflect the core of business and innovative operations at the firm level. The data utilized in the estimation of the regression functions is obtained from public statistics (The Central Statistical Office) and represents the time series of innovation and $R \& D$ expenditures and output measures exemplified by EBIDT and its relative growth. The econometric estimations are based on the total sample of 191 firms permanently (in every year of the 2000-2009 time series) active in the field of R\&D over the observed 10 year period. The subsample of firms representing the highest regularity in terms of $R \& D$ effort was taken under consideration since the previous estimations carried out by author on the basis of subsample of firms representing very high regularity in terms of business $R \& D$ activities gave promising results. Another rationale for this approach is the paper limitations.

The data cover the period between year 2000 and 2009. Estimations include the 0 to 6 years lag of independent variables which results with the maximum of 764 observations for the sample of firms taken under consideration in estimations presented in the paper. The firms covered by the survey represent medium and large (by EU standards) manufacturing companies located in all parts of
Poland. Only medium and large companies, that employ 50+ persons are taken into consideration in the study, since smaller (employing less than 50 persons) are not covered by the yearly survey of innovative activities (PNT-02 survey) carried out by The Central Statistical Office in Poland.

The initial version of the regression function is specified underneath.

$$
\begin{aligned}
& \frac{E B I T D^{*}{ }_{t}-E B I T D^{*}{ }_{t-1}}{E B I T D^{*}{ }_{t-1}}=\beta 0+\beta 1 \frac{E M P_{t}-E M P_{t-1}}{E M P_{t-1}}+ \\
& \beta 2 \frac{R \& \text { Int }_{t}}{y_{t}}+\beta 3 \frac{R \& D E x t_{t}}{y_{t}}+\beta 4 \frac{N I E_{t}}{y_{t}}+ \\
& \beta 5 \frac{\text { IETech }_{t}}{y_{t}}+\beta 6 \frac{\text { ICESoft }}{y_{t}}+\beta 7 \frac{\text { IEBuild }}{y_{t}}+ \\
& \beta 8 \frac{\text { IEMDom }_{t}}{y_{t}}+\beta 9 \frac{\text { IEM Im } p_{t}}{y_{t}}+\beta 10 \frac{\text { IETrai }_{t}}{y_{t}}+ \\
& \beta 11 \frac{\text { IEMark }_{t}}{y_{t}}+\beta 12 \frac{\text { IE Re } m_{t}}{y_{t}}
\end{aligned}
$$

Description of variables:

EBITD - Earnings before interest tax and depreciation

EMP - total employment

R\&DInt - internal research and development expenditure

R\&DExt - external research and development expenditure

NIE - non-innovation capital expenditure

IETech - innovation expenditure on new technologies

IESoft - innovation expenditure on software

IEBuild - innovation expenditure on buildings (associated with innovative activities or investment)

IEMDom - innovation expenditure on domestically made machinery

IEMImp - innovation expenditure on imported machinery

IETrai - innovation expenditure on training (associated with innovative activities or investment)

IEMark - innovation expenditure on marketing

IERem - remaining innovation expenditure

On the basis of available data and common standards, business $\mathrm{R} \& \mathrm{D}$ expenditure is divided into two broad categories:

- Internal business research and development: Activities carried out by a particular business entity regardless of the sources of funds utilized to finance them. Internal R\&D expenditure includes both running costs and capital expenditure.

- External business research and development: Includes $\mathrm{R} \& \mathrm{D}$ activities performed outside of a particular business entity by both domestic and foreign contractors.

The issue of interpretation of the accrual meaning of fixed effects and variable effects of panel regression models requires careful insight and attention. Fixed effects are being used when one is only interested in analyzing the impact of variables that vary over the time. FE help to search for the relationship between predictor and outcome variables within an entity (country, person, company, etc.). "Each entity has its own individual characteristics that may or may not influence the predictor variables (for example being a male or female could influence the opinion toward certain issue or the political system of a particular country could have some effect on trade or GDP or the business practices of a company 
may influence its stock price). When using FE we assume that something within the individual may impact or bias the predictor or outcome variables and we need to control for this This is the rationale behind the assumption of the correlation between entity's error term and predictor variables. FE remove the effect of those time-invariant characteristics from the predictor variables so we can assess the predictors' net effect.

Another important assumption of the FE model is that those time-invariant characteristics are unique to the individual and should not be correlated with other individual characteristics. Each entity is different therefore the entity's error term and the constant (which captures individual characteristics) should not be correlated with the others. If the error terms are correlated then FE is no suitable since inferences may not be correct and you need to model that relationship (probably using random-effects), this is the main rationale for the Hausman test" [24].

\section{THE FINDINGS}

TABLE I: ClassiCAl LEAST SQUARE ESTIMATION (CLS) OF PANEL DATA, 764 OBSERVATIONS, MAXIMUM LAG APPLIED - 6 YEARS, DEPENDENT VARIABLE RELATIVE EBITD GROWTH

\begin{tabular}{lccccc}
\hline \hline & $\begin{array}{c}\text { Value of } \\
\text { coefficient }\end{array}$ & $\begin{array}{c}\text { Standard } \\
\text { error }\end{array}$ & $t$ statistics & $p$ level & \\
\hline \hline const & $-0,0101284$ & 0,247199 & $-0,0410$ & 0,96733 & \\
R\&D Int no lag & 20,6412 & 10,3229 & 1,9995 & 0,04591 & $* *$ \\
NIE no lag & $-4,64828$ & 2,2334 & $-2,0813$ & 0,03775 & $* *$ \\
R\&D Int lagged 1 & $-41,8191$ & 12,8173 & $-3,2627$ & 0,00115 & $* * *$ \\
year & & & & & \\
NIE lagged 1 year & 7,64197 & 2,53541 & 3,0141 & 0,00266 & $* * *$ \\
R\&D Int lagged 3 & 16,6591 & 9,45666 & 1,7616 & 0,07854 & $*$ \\
years & & & & & $*$ \\
R\&D Ext lagged 5 & $-33,0144$ & 19,7688 & $-1,6700$ & 0,09533 & $*$ \\
years & & & & & $*$ \\
IES oft lagged 5 & $-174,351$ & 90,6367 & $-1,9236$ & 0,05478 & $*$ \\
years & & & & & $*$ \\
R\&D Ext lagged 6 & 29,3269 & 16,4948 & 1,7779 & 0,07581 & $*$ \\
years & & & & & \\
\hline \hline
\end{tabular}

$* * *, * *$, and $*$ indicate significance at the 1,5 and 10 percent levels respectively.

\begin{tabular}{|c|c|c|c|}
\hline Dependent variable average & $-0,033723$ & $\begin{array}{l}\text { Standard deviation } \\
\text { of dependent } \\
\text { variable }\end{array}$ & 4,704085 \\
\hline Sum of squares of residual & 16213,51 & $\begin{array}{l}\text { Standard error of } \\
\text { residual }\end{array}$ & 4,634096 \\
\hline Determination coefficient R2 & 0,039711 & Adjusted R2 & 0,029535 \\
\hline $\begin{array}{l}\text { F (Fisher-Snedecor) statistic } \\
(8,755)\end{array}$ & 3,902661 & $\mathrm{p}$ value for $\mathrm{F}$ test & 0,000158 \\
\hline Log likelihood ratio & $-2251,091$ & $\begin{array}{l}\text { Akaika } \\
\text { information } \\
\text { criterion }\end{array}$ & 4520,183 \\
\hline $\begin{array}{l}\text { Schwarz-Bayesian } \\
\text { information criterion }\end{array}$ & 4561,930 & $\begin{array}{l}\text { Hannan-Quinn } \\
\text { information } \\
\text { criterion }\end{array}$ & 4536,255 \\
\hline $\begin{array}{l}\text { Autocorrelation of residual - } \\
\text { rho1 }\end{array}$ & 0,009581 & $\begin{array}{l}\text { Durbina-Watsona } \\
\text { Stat. }\end{array}$ & 1,144369 \\
\hline
\end{tabular}

Estimations of regression function based on panel model were carried out on the basis of data obtained from 191 firms observed over 10 years period of time. Firms included in the research sample reported $R \& D$ expenditure in every year of the time series. In order to examine the more delayed effects, the 0 to 6 year lag between dependent and independent variable was applied. In the first place the panel data estimations based on classical least square (CLS) estimation method were executed, then subject to the results of selected statistical tests the generalized least square (GLS) estimation method was taken advantage of. The results of initial estimation of the panel model based on the CLS method after the removal of insignificant variables are presented in the Table I.

On the basis of Breusch-Pagan test $(L M=0,000283616$ with $p=\operatorname{prob}($ chi-square $(1)>0,000283616)=0,986564)$ there is no reason to reject the $\mathrm{H} 0$ hypothesis that estimations based on CLS method are correct. The same conclusion was formulated on the basis of $F$ test $(F(190,565)=1,02214$ with $p=0,418982$ ).

The estimations presented in Table I show mixed results. Five out of eight statistically significant variables ale strictly related to business research and development activities (internal or external). This might suggest that the overall impact of business $\mathrm{R} \& \mathrm{D}$ over the relative EBIDT growth is very strong, if not predominant among other categories of innovative expenditures. The model showed that only three other than business R\&D categories of expenditures independent variables exert statistically significant impact over dependent variable: non innovative expenditure lagged 0 years and lagged one year, together with innovative expenditure on software lagged five years.

In regards to the part of independent variables one can observe certain regularity, which means that positive effects tend to occur as the lag applied increases, this is clearly the fact in the case of external business $R \& D$, non-innovative expenditure and to some extent in the case of internal business R\&D. The model shows that one can expect less delayed effects of internal business $R \& D$ expenditure in comparison with the results of external business expenditure. Since companies spend less on internal business R\&D that on external $\mathrm{R} \& \mathrm{D}$, one basic rationale behind this finding might be that simply supposedly larger and more formalized external R\&D undertakings are associated with longer period of time to execute $R \& D$ contracts in comparison with smaller internal $R \& D$ project that might take less time to execute and obtain visible (positive or negative results), but this is only an assumption since no data is available to verify this hypothesis. This issue is supposed to be deepened and verified in the future research.

The results of panel data estimations based on classical least square (CLS) method on carried out on a sample of 191 companies gave interesting but to certain extent inconsistent and difficult to interpret results, therefore second attempt was made to perform estimations on the basis of narrower sample of firms. The initial sample of 191 firms active in the field of business R\&D was narrowed down to the sample of 90 firm that met the following criteria - relative growth of EBITD $<100 \%$. Any firm that at least once in the time series showed greater than $100 \%$ relative EBITD growth was excluded from the final sample. The rationale behind this attempt was to avoid discontinuities and possible data errors regarding dependent variable, since large portion of firms showed unexpected and hard to explain and consider credible values of relative EBITD growth. Despite the issue of data credibility, greater than $100 \%$ variation of profit related 
dependent variable might suggest significant discontinuities and other extraordinary factors that cause complications to the estimation process and make final conclusions hard to formulate.

The panel data estimations on the basis of narrowed sample of 90 firms, based on the classical least square (CLS) method were rejected on the basis of Breusch-Pagan test ( $L M$ $=4,20562$ with $p=\operatorname{prob}($ chi-square $(1)>4,20562)=$ 0,0402902). As the result of this generalized least square (GLS) estimation method was applied and estimations of fixed effects and random effects models were carried out.

The estimations of fixed effects and random effects based on generalized least square (GLS) method on the basis of Hausman Test proved that random effects (RE) model is more efficient $(H=31,0965$ with $p=\operatorname{prob}($ chi-square(34) > $31,0965)=0,610686)$.

The $\mathrm{F}$ test for variation for constant proved that there is no re reason to reject the $\mathrm{H} 0$ hypothesis that groups have common constant $(F(89,236)=0,739935$ with $p=P(F(89$, 236) $>0,739935)=0,949746)$.

After rejection of insignificant variables the final version of the fixed effects model is presented in the Table II.

TABLE II: GENERALIZED LEAST SQUARE ESTIMATION (GLS) OF PANEL DATA, FiXed EFFECTS (FE), 360 OBSERVATIONS, 90 COMPANIES, MAXIMUM Lag APPlied - 6 Years, DePendent Variable Relative EBITD

\begin{tabular}{|c|c|c|c|c|c|}
\hline & $\begin{array}{c}\text { Value of } \\
\text { coefficient }\end{array}$ & $\begin{array}{l}\text { Standard } \\
\text { error }\end{array}$ & $T$ statistics & $p$ level & \\
\hline const & 0,191752 & 0,0448148 & 4,2788 & 0,00003 & $* * *$ \\
\hline $\begin{array}{l}\text { IEM Imp no } \\
\text { lag }\end{array}$ & $-1,42053$ & 0,521895 & $-2,7219$ & 0,00693 & $* * *$ \\
\hline IE Mark no lag & $-0,979834$ & 0,456895 & $-2,1446$ & 0,03291 & $* *$ \\
\hline $\begin{array}{l}\text { NIE lagged } 3 \\
\text { years }\end{array}$ & $-2,41067$ & 0,610005 & $-3,9519$ & 0,00010 & $* * *$ \\
\hline $\begin{array}{l}\text { IE Soft lagged } \\
3 \text { years }\end{array}$ & $-16,0759$ & 6,7959 & $-2,3655$ & 0,01873 & $* *$ \\
\hline $\begin{array}{l}\text { IE Build } \\
\text { lagged } 5 \text { years }\end{array}$ & $-2,67952$ & 1,29471 & $-2,0696$ & 0,03947 & $* *$ \\
\hline $\begin{array}{l}\text { NIE lagged } 6 \\
\text { years }\end{array}$ & $-1,52358$ & 0,565958 & $-2,6920$ & 0,00756 & $* * *$ \\
\hline
\end{tabular}

$* * *, * *$, and $*$ indicate significance at the 1,5 and 10 percent levels respectively.

\begin{tabular}{|c|c|c|c|}
\hline $\begin{array}{l}\text { Dependent variable } \\
\text { average }\end{array}$ & $-0,000837$ & $\begin{array}{l}\text { Standard deviation } \\
\text { of dependent } \\
\text { variable }\end{array}$ & 0,393390 \\
\hline $\begin{array}{l}\text { Sum of squares of } \\
\text { residual }\end{array}$ & 38,32865 & $\begin{array}{l}\text { Standard error of } \\
\text { residual }\end{array}$ & 0,382482 \\
\hline $\begin{array}{l}\text { Determination } \\
\text { coefficient R2 }\end{array}$ & 0,310106 & Adjusted R2 & 0,054688 \\
\hline $\begin{array}{l}\text { F (Fisher-Snedecor) } \\
\text { statistic }(97,262)\end{array}$ & 1,214111 & $\mathrm{p}$ value for $\mathrm{F}$ test & 0,116071 \\
\hline Log likelihood ratio & $-107,6347$ & $\begin{array}{l}\text { Akaika information } \\
\text { criterion }\end{array}$ & 411,2694 \\
\hline $\begin{array}{l}\text { Schwarz-Bayesian } \\
\text { information criterion }\end{array}$ & 792,1076 & $\begin{array}{l}\text { Hannan-Quinn } \\
\text { information criterion }\end{array}$ & 562,6979 \\
\hline $\begin{array}{l}\text { Autocorrelation of } \\
\text { residual - rho1 }\end{array}$ & $-0,335610$ & $\begin{array}{l}\text { Durbina-Watsona } \\
\text { Stat. }\end{array}$ & 1,978254 \\
\hline
\end{tabular}

The results of estimation of fixed effects model (included as a reference) show negative values/effects of all statistically significant parameters. This itself is an interesting finding since it suggests that all (if any) positive effect of innovative expenditure might come from other - individual, mostly time invariant individual characteristics of companies in the sample. The removal the effect of those time-invariant characteristics from the predictor variables in the case of FE estimation, allows to assess the predictors' net effect which in this case seems to be negative. One can argue that the expenditure itself is in a sense a prerequisite, and the actual efficiency of innovative expenditure is determined not by innovative expenditure itself but by other unique characteristics of the given company. The net effect of innovative expenditure itself (separated from those unique individual characteristic is (in the light of the above) negative since it only increases costs and therefore reduces EBITD relative growth. The by far greatest value of the coefficient estimated for innovative expenditure on software lagged three years (equals -16, 0759) is itself an interesting (and hard to interpret) finding since it may suggest that the positive effect of innovative expenditure on software heavily depends in unique time invariant characteristics of individual firms and has to be especially carefully managed and reflect these specific characteristics in order to ensure positive returns. This might also be the case as far as other statistically significant parameters are concerned but to far smaller extent. The smallest value of estimated coefficient was estimated in case of innovative expenditure on marketing (the value of the coefficient equals $-0,979834)$. This might suggest that the effect of this category of innovative expenditure is to the smallest extent susceptible to the unique time invariant characteristics of the firm. The positive effect might be ensured to far greater extent by the expenditure itself.

The results of GLS estimations of regression function presented in the Table III prove in the first place consistent and positive impact of business $R \& D$ expenditure (both internal and external) on relative EBIDT growth. Strong positive and statistically significant three years lagged impact (value of estimated coefficient $=11,3$ ) of external business R\&D expenditure was observed. Subsequently on top of this relatively strong and positive five years lagged impact of both internal (value of estimated coefficient $=3,2$ ) and external (value of estimated coefficient $=3,3$ ) business R\&D was identified. All the other statistically significant independent variables presented in Table III have either negative or mixed (both positive and negative subject to lagged applied) impact over dependent variable. In the light if the research evidence of random effects regression model specified in Table III business research and development expenditure has the strongest positive impact over relative EBIDT growth among all the other components of innovation expenditure specified in the model. On top of this the research evidence suggest that external business R\&D might be more effective and bring less delayed effects in comparison to the internal business $\mathrm{R} \& \mathrm{D}$. This finding confirms the results of previous estimations and further supports the assumption that external business R\&D represents more effective option that internal business R\&D in the case of emerging and transition economies. External performers of business R\&D might have greater experience and usually well-defined contracted external business R\&D may provide noticeably higher probability of success and stronger supports profit growth. In the case of some other independent variables (innovative expenditure on new technologies and remaining innovative expenditures) one can observe the buildup of positive returns with time, as the 
lagged increases. One should note that in the case of innovative expenditure on software the opposite trend was observed.

TABLE III: GeNeralized LeASt SQuare ESTIMATION (GLS) OF PANEL

DATA, RANDOM EFFECTS (RE), 360 OBSERVATIONS, MAXIMUM LAG APPLIED - 6 YeARS, DEPENDENT VARIABLE RELATIVE EBITD GROWTH.

\begin{tabular}{lccccc}
\hline \hline & $\begin{array}{c}\text { Value of } \\
\text { coefficient }\end{array}$ & $\begin{array}{c}\text { Standard } \\
\text { error }\end{array}$ & $t$ statistics & $p$ level & \\
\hline \hline const & 0,134123 & 0,0336334 & 3,9878 & 0,00008 & $* * *$ \\
IEMImp no lag & $-1,12945$ & 0,419532 & $-2,6922$ & 0,00747 & $* * *$ \\
IEMark no lag & $-0,728749$ & 0,351994 & $-2,0703$ & 0,03921 & $* *$ \\
IESoft lagged one year & 11,722 & 6,59754 & 1,7767 & 0,07655 & $*$ \\
IETrain lagged two years & $-97,8778$ & 38,6835 & $-2,5302$ & 0,01187 & $* *$ \\
IERem lagged 2 years & 14,0002 & 4,5752 & 3,0600 & 0,00240 & $* * *$ \\
R\&DExt lagged 3 years & 11,3588 & 4,74183 & 2,3954 & 0,01717 & $* *$ \\
NIE lagged 3 years & $-1,46884$ & 0,41144 & $-3,5700$ & 0,00041 & $* * *$ \\
IESoft lagged 3 years & $-12,5258$ & 4,99188 & $-2,5092$ & 0,01259 & $* *$ \\
IEMark lagged 3 years & $-5,0372$ & 2,68464 & $-1,8763$ & 0,06151 & $*$ \\
IERem lagged 3 years & $-10,0296$ & 3,06937 & $-3,2676$ & 0,00120 & $* * *$ \\
IEBuild lagged 4 years & $-2,1834$ & 1,15489 & $-1,8906$ & 0,05957 & $*$ \\
IERem lagged 4 years & 5,56559 & 2,03679 & 2,7325 & 0,00663 & $* * *$ \\
R\&DInt lagged 5 years & 3,26177 & 0,962757 & 3,3880 & 0,00079 & $* * *$ \\
R\&DExt lagged 5 years & 3,33946 & 2,00923 & 1,6621 & 0,09746 & $*$ \\
IETech lagged 5 years & $-7,2142$ & 3,93129 & $-1,8351$ & 0,06741 & $*$ \\
IEBuild lagged 5 years & $-2,74735$ & 1,04612 & $-2,6262$ & 0,00904 & $* * *$ \\
NIE lagged 6 years & $-0,854331$ & 0,394894 & $-2,1634$ & 0,03124 & $* *$ \\
IETech lagged 6 years & 8,64667 & 3,39917 & 2,5438 & 0,01143 & $* *$ \\
IERem lagged 6 years & $-3,942$ & 1,55708 & $-2,5317$ & 0,01182 & $* *$ \\
\hline \hline
\end{tabular}

$* * *, * *$, and $*$ indicate significance at the 1,5 and 10 percent levels respectively.

\begin{tabular}{|c|c|c|c|}
\hline $\begin{array}{l}\text { Dependent variable } \\
\text { average }\end{array}$ & $-0,000837$ & $\begin{array}{l}\text { Standard deviation of } \\
\text { dependent variable }\end{array}$ & 0,393390 \\
\hline $\begin{array}{l}\text { Sum of squares of } \\
\text { residual }\end{array}$ & 41,67047 & $\begin{array}{l}\text { Standard error of } \\
\text { residual }\end{array}$ & 0,357524 \\
\hline Log likelihood ratio & $-122,6818$ & $\begin{array}{l}\text { Akaika information } \\
\text { criterion }\end{array}$ & 315,3637 \\
\hline $\begin{array}{l}\text { chwarz-Bayesian } \\
\text { formation criterio }\end{array}$ & 451,3773 & $\begin{array}{l}\text { Hannan-Quinn } \\
\text { information criterion }\end{array}$ & 369,4453 \\
\hline
\end{tabular}

\section{CONCLUSION}

The results of panel data estimations based both on classical least square and generalized least square method revealed strong variation of the impact of various categories of innovative expenditure taken under consideration in the initial version of the model and high significance associated with mostly positive impact of both internal and external business R\&D effort over relative EBITD growth. The positive impact was found mainly in the case of random effects. The analysis of random effects of business R\&D activates indicate significant, positive and strong to moderate impact of this category of innovative effort. Random effect data analysis revealed that the results of external $R \& D$ are less lagged (three) and stronger than the effects of internal business R\&D (five years lag). These conclusions formulated on the basis of the narrowed subsample and generalized least square estimation method of panel data analysis are in that particular respect opposite to the results of estimations based on classical least square method presented earlier in the paper. It seems to be worthwhile to further investigate this issue and find out if there is in fact certain regularity in terns the timing of effects of internal and external business R\&D, or such regularity in fact does not exist. The more in depth investigation of the complexity and true factors determining the effectiveness of business innovative effort with the special emphasis on business R\&D effort is vital for the overall development of the competitiveness of business units and via optimization of innovation and R\&D effort might encourage companies to on one hand spend more on innovation and on the other gain healthier returns for both private and social good.

\section{ACKNOWLEDGMENT}

Author would like to express special thanks to Prof. Jan Jacek Sztaudynger from Faculty of Economics and Sociology of University of Lodz and Prof. Marek Szajt from Faculty of Management of Czestochowa University of Technology for their support in the field of model specification and refinement. Without this support and suggestions the work that has led to this and other research papers would have been impossible. Author would like also to thank the Lodz Statistical Office for the support and provision of data regarding the input and output measures of manufacturing enterprises and especially Dr Artur Mikulec for his important support in the field of data handling and processing.

\section{REFERENCES}

[1] E. F. Denison, 'The sources of economic growth in the united states and the alternatives before US," Committee for Economic Development, New York, 1962.

[2] R. M. Sollow, "Technical change and the aggregate production function," Review of Economics and Statistics, vol. 39, 1957.

[3] P. M. Romer, "Endogenous technical change," Journal of Political Economy, vol. 98, 1990.

[4] L Sveikauskas, "R\&D and productivity growth: A review of the literature," US Bureau of Labor Statistics, Working Paper, no. 408, 2007.

[5] M. Martin, "The effectiveness of business innovative activities in the case of emerging economies; the exploration of relative sales growth model," International Journal of Applied Social Science Research, vol. 2, 2013.

[6] M. Martin, "The Effectiveness of Business Innovation Activities in the Case of Emerging Economies; in Search for the Lagged Effects," International Journal of Business, Management and Social Sciences, vol. II, issue 10(II), 2013.

[7] A. Kandybin, "Which innovation efforts will pay," MIT Sloan Management Review, vol. 51, issue 1, 2009.

[8] P. S. Koku, "R\&D expenditure and profitability in the pharmaceutical industry in the united states," Journal of Applied Management Accounting Research, vol. 8, issue 1, 2010.

[9] A. M. Bobillo, J. A. R Sanz, and F. T Gaite, "Innovation investment, competitiveness and performance in industrial firms," Thunderbird International Business Review, vol. 48, issue 6, 2006.

[10] S. K. Evily and B. Chakravarthy, "Resource context and the returns to investments in R\&D," Academy of Management Proceedings and Membership Directory, 1999.

[11] H. Li and K. A. Gima, "Product innovation strategy and the performance of the new technology ventures in china," Academy of Management Journal, vol. 44, issue 6, 2001.

[12] I. Hashia and N. Stojčićc, "The impact of innovation activities on firm rerformance using a multi-stage model: evidence from the community innovation survey 4," Research Policy, vol. 42, issue 2, 2013.

[13] J. Mataa and M. Woerter, "Risky innovation: The impact of internal and external R\&D strategies upon the distribution of returns," Research Policy, vol. 42, issue 2, 2013. 
[14] A. Triguero and D. Corcoles, "Understanding innovation: An analysis of persistence for Spanish manufacturing firms," Research Policy, vol. 42, issue 2, 2013.

[15] S. Pandit, C. E. Wasley, and T. Zach, "The effect of research and development $(R \& D)$ inputs and outputs on the relation between the uncertainty of future operating performance and $R \& D$ expenditures," Journal of Accounting, Auditing and Finance, 2011.

[16] K. W. Artz, P. M. Norman, D. E. Hatfield, and L. B. Cardinal, "Longitudinal study of the impact of R\&D, patents, and product innovation on firm performance," Journal of Product Innovation Management, vol. 27, Issue 5, 2010.

[17] A. Leiponen, "Competencies, innovation and profitability of firms," Economics of Innovation and New Technology, vol. 9, issue 1, 2000.

[18] M. P. Drake, N. Sakkab, and R. Jonash, "Maximizing return on innovation investment: Spending more on innovation does not necessarily translate into accelerating sales, market share or profit," Research-Technology Management, Nov.-Dec., 2006.

[19] M. S. Brenner and B. M. Rushton, "Sales growth and R\&D in the chemical industry," Research-Technology Management, vol. 32, no. 2, 1989.

[20] M. Pianta and A. Vaona, "Innovation and productivity in european industries," Economics of Innovation and New Technology, vol. 16, no. 7, 2007.

[21] R. Veugelers, "Internal R\&D expenditures and external technology sourcing," Research Policy, vol. 26, no. 3, 1997.

[22] D. B. Audretsch, A. J. Menkveld, and A. R. Thurik, "The decisions between internall and external R\&D," Journal of Institutional and Theoretical Economics, vol. 152, issues 3, 1996.

[23] A. D. Little, "Good innovation management increases profitability by 13\%," Business Wire (English), February, 2013.

[24] O. T. Reyna, "Panel data analysis, fixed \& random effects," Data and Statistical Services, Princeton University.

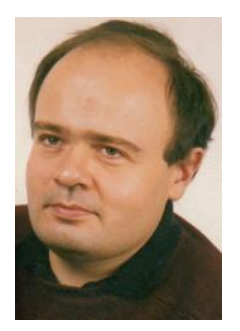

Marek Martin was born in Lodz, Poland on 23 August 1967. He graduated in 1992 from Technical University of Lodz, Poland. In 2002 he gained Ph.D. in economics at University of Lodz, Poland. He studied as Tempus student at University of Strathclyde in Glasgow, UK and Universidade Nova de Lisboa in Lisbon, Portugal. $\mathrm{He}$ did research project at University of Central England in Birmingham with conjunction with Aston Science Park Birmingham, UK during Tempus funded placement. The major fields of study include microeconomic aspect of innovative activities, management of technologies and economic aspects of development of selected fields of technology oriented firms i.e. biotechnology and energy technologies.

As a student and shortly after, he worked as diver and lifeguard. He worked as consultant for several business consulting firms and director of Lodz branch of finance and leasing association, Wroclaw, Poland. At the present moment he works as the assistant professor at Division of Economics, Institute of social science, Faculty of organization and management, Lodz University of Technology, Lodz, Poland. Previous research interests include problems of development and barriers to growth of new technology based firms, financing technology based ventures and academic entrepreneurship. Current interests include problems related to management of innovation, effectiveness of innovative and research and development activities, development of biotechnology companies in emerging markets and selected economic aspects of energy issues.

Dr. Martin is a member of Polish Economic Society. He obtained Outstanding Research Award from The Institute for Business and Finance Research, Hilo, USA. He worked as the reviver for international scientific journal and editor of several monographs summarizing research projects and international conference monographs. 